\title{
Effects of progesterone and anti-progestin (mifepristone) treatment on proliferation and apoptosis of the human ovarian cancer cell line, OVCAR-3
}

\author{
RAFFAÈLE FAUVET ${ }^{1,2}$, CHARLOTTE DUFOURNET ETIENNE ${ }^{1}$, CHRISTOPHE PONCELET ${ }^{2}$, \\ ANNIE-FRANCE BRINGUIER ${ }^{2}$, GÉRARD FELDMANN ${ }^{2}$ and EMILE DARA İ ${ }^{1,2}$ \\ ${ }^{1}$ Service de Gynécologie-Obstétrique, Hôpital Tenon, Faculté Saint-Antoine, Assistance Publique des Hôpitaux \\ de Paris; ${ }^{2}$ Laboratoire de Biologie Cellulaire, INSERM U327, Faculté Bichat-Claude Bernard, Paris, France
}

Received November 30, 2005; Accepted January 9, 2006

\begin{abstract}
The study examined the effects of various progesterone and mifepristone concentrations on the proliferation and apoptosis of the human ovarian cancer cell line, OVCAR-3. OVCAR-3 cells were incubated with progesterone and mifepristone at concentrations ranging from $10^{-3}$ to $10^{-9} \mathrm{M}$. Proliferation and apoptosis were studied by means of inverted optical microscopy, DAPI staining, and crystal violet assay. Immunoblotting was used to study the regulation of the apoptosis-related proteins, bcl-2, caspase-3 and PARP, after incubation with various reagents. OVCAR-3 cell density was increased by progesterone concentrations of $10^{-5} \mathrm{M}$ or less, and decreased by $10^{-3} \mathrm{M}$ progesterone. DAPI staining showed no apoptotic bodies. Mifepristone concentrations of $10^{-3}$ and $10^{-4} \mathrm{M}$ reduced the OVCAR-3 cell density. Immunoblotting showed PARP cleavage in the presence of mifepristone $10^{-4} \mathrm{M}$. Caspase- 3 and bcl-2 expression was reduced by mifepristone $10^{-4}$ and $10^{-7} \mathrm{M}$. These results suggest that progesterone has a paradoxical effect on OVCAR-3 cell proliferation, stimulating it at low concentrations and inhibiting it at high concentrations, potentially through a caspase-independent non-apoptotic death pathway. Mifepristone seems to inhibit OVCAR-3 cell proliferation by down-regulating bcl-2 and up-regulating caspase- 3 activity. These preliminary results suggest that progesterone and mifepristone have beneficial effects in ovarian cancer.
\end{abstract}

\section{Introduction}

Epithelial ovarian cancer is the leading cause of death by gynaecological malignancy $(1,2)$. Hormonal regulation of

\footnotetext{
Correspondence to: Professor Emile Daraï, Service de GynécologieObstétrique, Hôpital Tenon, 4 rue de la Chine, 75020 Paris, France E-mail: emile.darai@tnn.ap-hop-paris.fr
}

Key words: apoptosis, progesterone, anti-progestin, OVCAR-3, culture cell ovarian carcinogenesis is suggested by the higher incidence after menopause, owing to variations in sex steroids and gonadotropins (3-6). In addition, women using combined oral contraception have a reduced risk of epithelial ovarian cancer (7-10).

Malignant transformation of normal ovarian epithelial cells is related to genetic alterations that disrupt the regulation of apoptosis, proliferation and DNA repair (11). Apoptosis, or programmed cell death, is an active physiological process that involves endonucleases and protease cleavage of DNA and proteins $(12,13)$. Yu et al (14) found that progesterone inhibited proliferation and promoted apoptosis of a human cell line derived from a malignant Brenner ovarian tumour. Bu et al (15) reported that progesterone induced apoptosis and up-regulated p53 expression in human ovarian cancer cell lines, without affecting bcl- 2 expression. In ovarian cancer cell lines, cell proliferation and apoptosis-related markers of genetic instability have been linked to the absence of steroid hormone receptors $(16,17)$.

Mifepristone (RU486) is a synthetic hormone antagonist that binds to progesterone receptors but not to oestrogen receptors. There is increasing evidence that mifepristone has potential as an anti-neoplastic agent (18). Although it has been reported to inhibit the growth of various malignant cell lines, the exact mechanism of cell death is unclear (19-22). An in vitro study suggested that mifepristone inhibited the proliferation of epithelial ovarian cancer cell lines by blocking cells in the G0/G1 phase of the cell cycle (22). Few data are available on the effects of progestins and anti-progestins on the proliferation and apoptosis of the OVCAR-3 human ovarian cancer cell line $(22,23)$.

The aims of this in vitro study were to evaluate the effects of various progesterone and mifepristone concentrations on the proliferation and apoptosis of OVCAR-3 cells.

\section{Materials and methods}

Cells and culture. The human ovarian carcinoma cell line, OVCAR-3, was obtained from ATCC (American Type Culture Collection, Rockville, MD, USA). OVCAR-3 cells were established from malignant ascites of a woman with progressive adenocarcinoma of the ovary after combination chemotherapy 


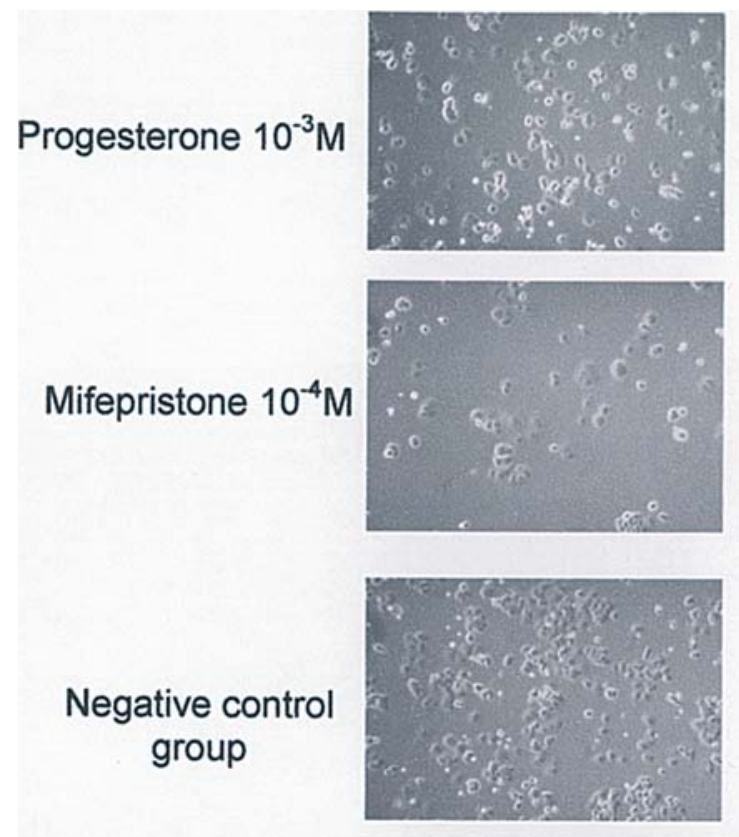

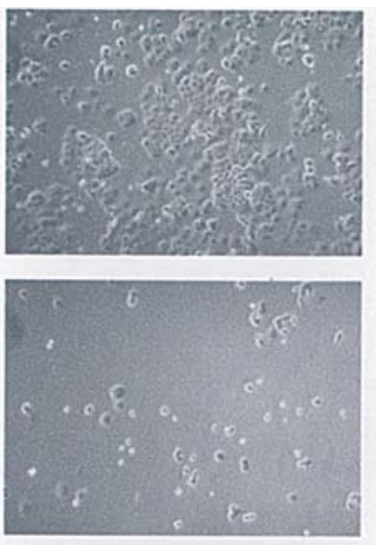

\section{Progesterone $10^{-7} \mathrm{M}$ \\ Progesterone $10^{-7} \mathrm{M}$}

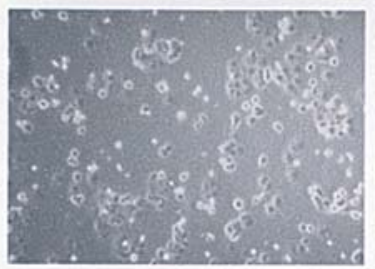
Mifepristone $10^{-7} \mathrm{M}$ (1)

\section{$5-\mathrm{FU} 1 \mathrm{mg} / \mathrm{mL}$}

Figure 1. Inverted optical microscopy shows an increased OVCAR-3 cell density by $10^{-7} \mathrm{M}$ progesterone and a reduced cell density by $10^{-3} \mathrm{M}$ progesterone compared to negative control group. OVCAR-3 cell density was reduced by $10^{-7}$ and $10^{-4} \mathrm{M}$ mifepristone, and by $5 \mathrm{FU} 1 \mathrm{mg} / \mathrm{ml}$.

with cyclophosphamide, adriamycin and cisplatin. OVCAR-3 cells contained cytoplasmic androgen- and oestrogen-binding macromolecules having the specificity of the hormone receptors of both steroids (24). The cell line was maintained at $37^{\circ} \mathrm{C}$ in medium containing 90\% Dulbecco's minimum essential medium (DMEM) (Life Technologies Ltd., Paisley, UK), $10 \%$ foetal bovine serum, penicillin and streptomycin $(100$ $\mathrm{IU} / \mathrm{ml})$ and gentamycin $(10 \mu \mathrm{g} / \mathrm{ml})$ (Life Technologies Ltd.), in humidified air with $5 \% \mathrm{CO}_{2}$. All cultures were routinely tested for mycoplasma.

Inverted optical microscopy. Cells were plated in DMEM containing the test reagents at various concentrations. The reagents were omitted in negative controls and replaced by 5 -FU $1 \mathrm{mg} / \mathrm{ml}$ in positive controls.

DAPI (4', 6-diamidino-2-phenylindole) staining. OVCAR-3 cell suspension $(40 \mu 1)$ was smeared on a glass slide, airdried, fixed for $10 \mathrm{~min}$ in $70 \%$ ethanol at room temperature, and dried again. The smears were then incubated for $5 \mathrm{~min}$ at room temperature with 1/2000 DAPI solution (Sigma, St. Louis, MO, USA) in Dulbecco's phosphate-buffered saline (PBS) (Eurobio, Les Ulis, France) containing 0.1\% Tween-20 (Sigma). They were then washed in PBS, dried and mounted in Mowiol solution (Calbiochem, San Diego, USA). Nuclear morphology was analysed under ultraviolet light with a x100 objective (Leica, Portugal).

Crystal violet assay. Cells were plated in triplicate in 96-well flat-bottomed plates at $10^{5}$ cells/well with $200 \mu 1$ of DMEM containing the test reagents at various concentrations. The supernatant was removed after $24 \mathrm{~h}$ of incubation and the cells were washed with $200 \mu 1$ of physiological saline and then fixed with $200 \mu \mathrm{l}$ of ethanol $\left(70^{\circ} \mathrm{C}\right)$ for $5 \mathrm{~min}$ at room temperature. The ethanol was removed by aspiration and the plates were air-dried at room temperature. The cells were then incubated with $50 \mu \mathrm{l} /$ well crystal violet for $5 \mathrm{~min}$ and washed with sterile water. Crystal violet was solubilized with $100 \mu \mathrm{l} /$ well acetic acid (33\% dilution). Optical density was measured at $550 \mathrm{~nm}$ with an Elisa microplate reader (Labsystem).

Cell density in the presence of the test reagents was expressed as a ratio of negative control cell density (arbitrarily 1 ). The mean \pm standard deviation (SD) cell density of negative controls, calculated for 12 culture wells, was $0.437 \pm 0.035$.

Immunoblot analysis. After $24 \mathrm{~h}$ of incubation, cells were centrifuged at $1500 \mathrm{x} \mathrm{g}$ for $3 \mathrm{~min}$. Pellets were suspended in $1 \mathrm{ml}$ of physiological saline and were again centrifuged at 2000 x g for $2 \mathrm{~min}$. Supernatants were carefully discarded and the pellets were carefully weighed. To prepare membrane/ cytoplasm and nuclear extracts, cells were prepared as described by Andrews and Faller (25). Briefly, cell pellets were resuspended in 10 volumes of hypotonic buffer A [10 mM Hepes-KOH (pH 7.9), $1.5 \mathrm{mM} \mathrm{MgCl}_{2}, 10 \mathrm{mM} \mathrm{KCl}, 1 \mathrm{mM}$ DTT (dithiothreitol), $0.5 \mathrm{mM}$ spermidine, $1 \mathrm{mM}$ PMSF (phenylmethylsulfonyl fluoride), $1 \mu \mathrm{g} / \mathrm{ml}$ leupeptin, $1 \mu \mathrm{g} / \mathrm{ml}$ aprotinin (Sigma)] for $10 \mathrm{~min}$ on ice and then mixed and centrifuged at $500 \mathrm{x} \mathrm{g}$ for $1 \mathrm{~min}$ at $4^{\circ} \mathrm{C}$. The supernatant was kept as the cytoplasmic extract. The nuclear pellet was treated with 5 volumes of hypertonic buffer B [20 mM Hepes-KOH (pH 7.9), 25\% glycerol, $0.4 \mathrm{M} \mathrm{NaCl}, 1.5 \mathrm{mM} \mathrm{MgCl} 2,20 \mu \mathrm{M}$ EDTA, 4 mM DTT, 1 mM PMSF, $1 \mu \mathrm{g} / \mathrm{ml}$ leupeptin, $1 \mu \mathrm{g} / \mathrm{ml}$ aprotinin] for $20 \mathrm{~min}$ on ice. Nuclear extracts were obtained by isolating the non-extractable chromatin residue by centrifugation at $18000 \mathrm{x}$ g for $2 \mathrm{~min}$ at $4^{\circ} \mathrm{C}$. The nuclear fraction was used to study poly(ADP-ribose) polymerase (PARP) cleavage, and the membrane/cytoplasmic fraction was used to analyse bcl-2 and caspase-3 expression. Membrane/cytoplasmic and nuclear extracts were submitted to SDS-PAGE 

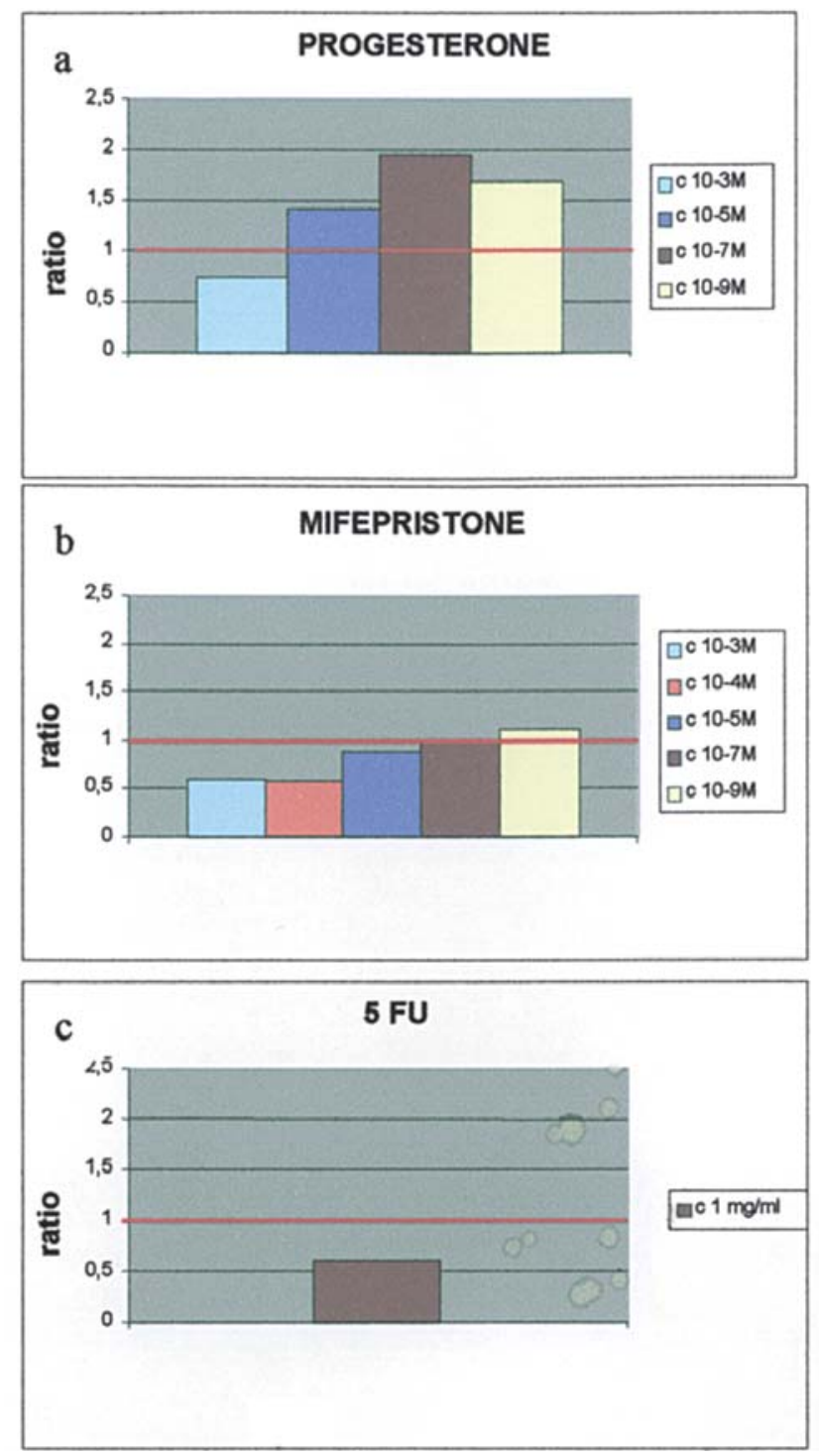

Figure 2. Crystal violet assay. Cell density was reduced by progesterone $10^{-3} \mathrm{M}$ and increased by progesterone $10^{-5}, 10^{-7}$ and $10^{-9} \mathrm{M}$ (a). Cell density was reduced by mifepristone $10^{-3}$ and $10^{-4} \mathrm{M}$. Cell density was unaffected by mifepristone $10^{-5}, 10^{-7}$ and $10^{-9} \mathrm{M}$ (b). $5 \mathrm{FU} 1 \mathrm{mg} / \mathrm{ml}$ reduced cell density (c).

electrophoresis (6\% polyacrylamide for PARP, $15 \%$ for bcl-2 and caspase-3) and electrophoretically transferred onto nitrocellulose membranes [B83 Schleicher \& Schuell (Dassel, Germany)]. Protein loading controls were used. To block nonspecific antigenic sites, the membranes were incubated in $5 \%$ non-fat dry milk in PBS containing $0.1 \%$ Tween-20.

Blots were probed for $1 \mathrm{~h}$ at room temperature with the following species-specific antibody diluted $1 / 1000$, as appropriate: anti-PARP monoclonal antibody, mouse IgG1 (clone C2-10) and anti-bcl-2 polyclonal rabbit antibodies were from Santa Cruz Biotechnology (Santa Cruz, CA, USA); and anti-pro-caspase-3 polyclonal rabbit antibody was from Pharmingen (San Diego, CA, USA).

Blots were then probed for $1 \mathrm{~h}$ with a second specific antibody (horseradish peroxidase-conjugated IgG) diluted 1/5000. After washing, chemiluminescence detection was performed with the ECL Western blot detection system from Amersham (Buckinghamshire, UK) according to the manufacturer's instructions, and the membrane was exposed to X-ray film for 5-10 min. All techniques were duplicated.

Statistical analysis. Continuous variables were compared with the Kruskall-Wallis and Mann-Whitney tests. P-values $<0.05$ were considered significant.

\section{Results}

Microscopic analysis (Fig. 1). OVCAR-3 cells were incubated for $24 \mathrm{~h}$ with progesterone $10^{-3}$ and $10^{-7} \mathrm{M}$, mifepristone $10^{-4}$ and $10^{-7} \mathrm{M}, 5 \mathrm{FU} 1 \mathrm{mg} / \mathrm{ml}$ (positive control) or medium alone (negative control).

Compared to the negative controls, the cell density was increased by $10^{-7} \mathrm{M}$ progesterone and reduced by $10^{-3} \mathrm{M}$ progesterone. The cell density was reduced by $10^{-7}$ and $10^{-4} \mathrm{M}$ mifepristone, and by $5 \mathrm{FU} 1 \mathrm{mg} / \mathrm{ml}$.

Crystal violet assay (Fig. 2). OVCAR-3 cells were incubated for $24 \mathrm{~h}$ with progesterone $10^{-3}, 10^{-5}, 10^{-7}$ and $10^{-9} \mathrm{M}$, mifepristone $10^{-3}, 10^{-4}, 10^{-5}, 10^{-7}$ and $10^{-9} \mathrm{M}$, and $5 \mathrm{FU} 1 \mathrm{mg} / \mathrm{ml}$.

The cell density was reduced by progesterone $10^{-3} \mathrm{M}$ $(\mathrm{p}=0.02$; ratio $=0.74 \pm 0.03)$ and increased by progesterone $10^{-5} \mathrm{M}(\mathrm{p}=0.03$; ratio $=1.42 \pm 0.22), 10^{-7} \mathrm{M}(\mathrm{p}=0.02$; ratio $=$ $1.95 \pm 0.05)$ and $10^{-9} \mathrm{M}(\mathrm{p}=0.03$; ratio $=1.69 \pm 0.36)$.

The cell density was reduced by mifepristone $10^{-3} \mathrm{M}$ $(\mathrm{p}=0.02$; ratio $=0.60 \pm 0.03)$ and $10^{-4} \mathrm{M}(\mathrm{p}=0.02$; ratio $=$ $0.59 \pm 0.04$ ), and was unaffected by mifepristone $10^{-5} \mathrm{M}$ (ratio = $0.87 \pm 0.05), 10^{-7} \mathrm{M}$ (ratio $=1.00 \pm 0.03$ ) and $10^{-9} \mathrm{M}$ (ratio $=$ $1.12 \pm 0.04)$.

$5 \mathrm{FU} 1 \mathrm{mg} / \mathrm{ml}$ reduced the cell density $(\mathrm{p}=0.02$; ratio $=$ $0.61 \pm 0.06$ ) , as did mifepristone $10^{-3}$ and $10^{-4} \mathrm{M}$ and $5 \mathrm{FU} 1 \mathrm{mg} /$ $\mathrm{ml}$, to a similar extent $(\mathrm{p}=0.96)$.

DAPI staining (Fig. 3). Microscopic examination of apoptotic segmented nuclei/cells stained by DAPI showed that $5 \mathrm{FU}$ $1 \mathrm{mg} / \mathrm{ml}$ induced apoptosis. No apoptotic bodies were observed with progesterone $10-3 \mathrm{M}$ or with mifepristone $10^{-3} \mathrm{M}$. Progesterone enlarged cells but did not produce genuine apoptotic bodies.

Immunoblotting (Fig. 4). OVCAR-3 cells were incubated for $24 \mathrm{~h}$ with progesterone $10^{-3}$ and $10^{-7} \mathrm{M}$, mifepristone $10^{-4}$ and $10^{-7} \mathrm{M}, 5 \mathrm{FU} 1 \mathrm{mg} / \mathrm{ml}$ (positive control) or medium alone (negative control). Spontaneous apoptosis was observed in the negative control group, as confirmed by PARP cleavage.

PARP cleavage was also observed with mifepristone $10^{-4} \mathrm{M}$ and with 5FU. All mifepristone concentrations reduced caspase- 3 and bcl-2 expression.

Progesterone did not affect caspase-3 or bcl-2 expression. The $115-\mathrm{kD}$ PARP band was reduced by progesterone $10^{-3} \mathrm{M}$, without PARP cleavage.

\section{Discussion}

This in vitro study confirms that proliferation and apoptosis of the OVCAR-3 cell line are differently affected by various progesterone and mifepristone concentrations.

Progesterone has been used in the treatment of ovarian cancer, but its mechanism of action is not fully understood. 
A

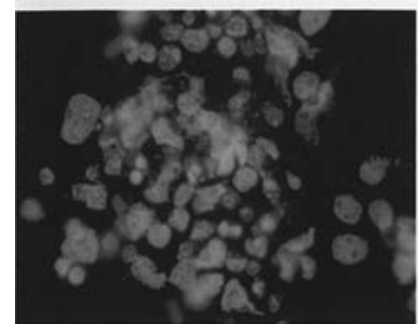

B

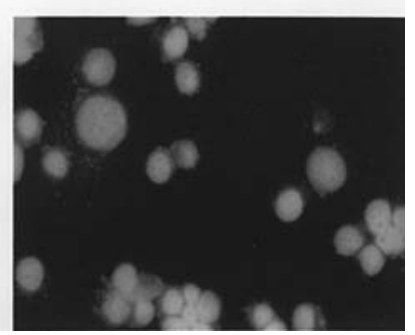

Figure 3. Fluorescence microscopic examination (DAPI staining after $24 \mathrm{~h}$ of incubation) shows apoptotic bodies induced by $5 \mathrm{FU} 1 \mathrm{mg} / \mathrm{ml}$ (A). Progesterone $10^{-3} \mathrm{M}$ enlarged cells but did not produce genuine apoptotic bodies (B).

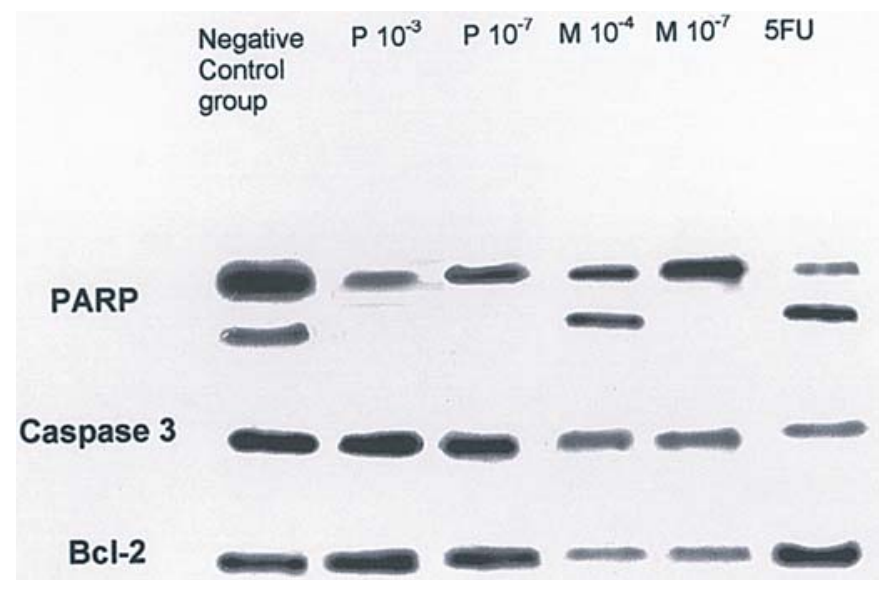

Figure 4. Immunoblot analysis shows a spontaneous apoptosis in the negative control group, as confirmed by PARP cleavage. PARP cleavage was also observed with mifepristone $10^{-4} \mathrm{M}$ and with $5 \mathrm{FU}$. Mifepristone at $10^{-4}$ and $10^{-7}$ reduced caspase- 3 and bcl-2 expression. The $115-\mathrm{kD}$ PARP band was reduced by progesterone $10^{-3} \mathrm{M}$, without PARP cleavage.

In this setting, as in the current study, progesterone is generally used at a concentration 10-100 times higher than that observed during the luteal phase (26). We found that OVCAR-3 cell density was increased by progesterone concentrations of $10^{-5} \mathrm{M}$ or less, while it was reduced by a concentration of $10^{-3} \mathrm{M}$. Our results partly disagree with those of Feng et al (27), who reported that progesterone concentrations of $10^{-5} \mathrm{M}$ or more inhibited the growth of ovarian cancer cells in vitro. This apparent discrepancy may be due to the use of different ovarian cancer cell lines (3AO and $\mathrm{AO}$ ) with different steroid receptor affinity for progesterone. We found that progesterone stimulated cell proliferation at a low concentration but inhibited it at high concentrations. In contrast, $\mathrm{Bu}$ et al (15) reported that the inhibitory effect of progesterone on ovarian cancer cell growth in vitro was concentration-dependent. However, these latter authors only tested two concentrations of progesterone. Our results are in keeping with those of Syed and Ho (28) showing that low progesterone concentrations promoted the growth of normal and malignant ovarian epithelial surface cells while high concentrations had an inhibitory effect. Although $10^{-3} \mathrm{M}$ progesterone reduced OVCAR-3 cell density in our study, it is important to note that this inhibitory effect was weaker than that of $5 \mathrm{FU}$.

The anti-tumoural action of progesterone involves apoptosis (14), modulation of inducible nitric oxide synthase (29), altered plasma membrane fluid dynamics (30) and alternative expression of transforming growth factors (31). In our study, DAPI staining revealed large cells but no apoptotic bodies in the presence of progesterone. This suggests that progesterone at a concentration of $10^{-3} \mathrm{M}$ reduces OVCAR-3 cell density potentially via a cell death pathway other than the classical apoptosis pathway described by Kerr et al (32). However, further analysis using electron microscopy or pan-caspase inhibitor z-VAD-fmk would be required to confirm this hypothesis. Immunoblotting showed no effect of progesterone on caspase-3 expression, suggesting a caspase-independent death pathway.

Mifepristone reduced OVCAR-3 cell density when used at concentrations of $10^{-3}$ and $10^{-4} \mathrm{M}$, to an extent similar to that observed with $5 \mathrm{FU} 1 \mathrm{mg} / \mathrm{ml}$. Lower mifepristone concentrations had no such effect. These results are in keeping with those of studies showing an anti-proliferative effect of mifepristone on various cancer cell lines (22,33-35). Rose and Barnea (22) reported mifepristone concentration-dependent growth inhibition of several human ovarian epithelial cancer cell lines expressing progesterone receptors. However, we found that mifepristone concentrations lower than $10^{-4} \mathrm{M}$ had no inhibitory action on OVCAR-3 cell proliferation. This apparent discrepancy could be explained by our relatively short incubation period $(24 \mathrm{~h})$ with mifepristone. Indeed, mifepristone effects are both concentration- and time-dependent $(22,36)$. Mifepristone down-regulates progesterone-receptor expression in cancer cell lines and blocks cells in G0/G1 phase, thereby reducing the number of cells in $S$ phase $(22,34,35,37)$. Our immunoblotting results show that mifepristone plays a crucial role in OVCAR-3 apoptosis. Indeed, PARP cleavage and reduced bcl-2 and caspase- 3 expression were observed in the presence of mifepristone, at levels similar to those observed with 5FU. Our results are in keeping with those of Wang et al (35), showing that mifepristone induced concentration-dependent apoptosis of the ovarian cancer cell line, SKOV3. Moreover, Li et al (36) found that the antitumoural effect of mifepristone on the ovarian cancer cell line, $3 \mathrm{AO}$, was related to bcl-2 protein down-regulation. This effect has also been found in other cancer cell lines $(33,38)$. Qin and Wang (39) suggested that mifepristone acts by enhancing the sensitivity of ovarian cancer cells to chemotherapy, possibly by regulating bcl-2 and bax protein expression. Some studies have suggested a regulatory effect of mifepristone on apoptosis-related proteins, with up-regulation of $\mathrm{p} 53$ in ovarian cancer cells $(15,36)$ and $\mathrm{p} 21^{\mathrm{WAF} / \mathrm{ip} 1}$ in breast cancer cells (40), and down-regulation of bcl- $\mathrm{x}_{\mathrm{L}}$ in gastric adenocarcinoma cells (34).

Our immunoblotting experiments showed that mifepristone reduced caspase- 3 expression. This is in keeping with the results of Pollett et al (41), who studied caspase-3 regulation by mifepristone in myeloma cells. They found that caspase- 3 levels were below the Western blot detection level after $24 \mathrm{~h}$ of incubation, and confirmed the up-regulation and activation of caspase- 3 following mifepristone induction, by means of active-caspase-3-specific Western blotting. In our 
study, the functional activity of caspase- 3 may be confirmed by the detection of PARP cleavage products. Up-regulation of caspase- 3 activity by mifepristone was also reported by $\mathrm{Li}$ et al (34), in a human gastric adenocarcinoma cell line.

From the clinical point of view, our results support the concept that mifepristone could play a role in the adjuvant treatment of ovarian cancer. Previous in vitro and in vivo studies have shown that mifepristone can inhibit the growth of chemoresistant human ovarian carcinoma and enhance its sensitivity to cis-platinum $(35,39,42)$. Moreover, a clinical trial has shown that mifepristone is well tolerated and effective in patients with ovarian cancer resistant to cisplatin and paclitaxel (43). Some of the limitations of the current study are as follows: first, the use of only one cell line of ovarian cancer established from malignant ascites of a woman previously treated by chemotherapy; second, only data obtained after $24 \mathrm{~h}$ of incubation were available and should be confirmed using longer incubation periods; and finally, quantitation of apoptosis by trypan blue staining or TUNEL analysis could also be relevant.

In conclusion, our results support the potential effects of progesterone and anti-progestin treatment on the proliferation and apoptosis of the OVCAR-3 cell line. Progesterone at a concentration of $10^{-3} \mathrm{M}$ inhibited OVCAR-3 cell proliferation potentially via a caspase-independent death pathway different to that of apoptosis. Moreover, mifepristone seems to inhibit ovarian cancer cell lines by down-regulating bcl-2 and upregulating caspase-3 activity. Our preliminary results suggest that progesterone, and especially mifepristone, could be useful in the treatment of ovarian cancer.

\section{References}

1. Risch HA: Hormonal etiology of epithelial ovarian cancer, with a hypothesis concerning the role of androgens and progesterone. J Natl Cancer Inst 90: 1774-1786, 1998.

2. Rose PG, Nerenstone S, Brady MF, et al: Secondary surgical cytoreduction for advanced ovarian carcinoma. N Engl J Med 351: 2489-2497, 2004.

3. Schneider HP and Birkhauser M: Does HRT modify risk of gynecological cancers? Int J Fertil Menopausal Stud 40 (suppl 1): 40-53, 1995.

4. Riman T, Nilsson S and Persson IR: Review of epidemiological evidence for reproductive and hormonal factors in relation to the risk of epithelial ovarian malignancies. Acta Obstet Gynecol Scand 83: 783-795, 2004.

5. Pike MC, Krailo MD, Henderson BE, Casagrande JT and Hoel DG: 'Hormonal' risk factors, 'breast tissue age' and the ageincidence of breast cancer. Nature 303: 767-770, 1983.

6. Konishi I, Kuroda $\mathrm{H}$ and Mandai M: Review: gonadotropins and development of ovarian cancer. Oncology 57 (suppl 2): 45-48, 1999.

7. Whittemore AS, Harris R and Itnyre J: Characteristics relating to ovarian cancer risk: collaborative analysis of 12 US case-control studies. IV. The pathogenesis of epithelial ovarian cancer. Collaborative Ovarian Cancer Group. Am J Epidemiol 136: 1212-1220, 1992.

8. Hankinson SE, Colditz GA, Hunter DJ, Spencer TL, Rosner B and Stampfer MJ: A quantitative assessment of oral contraceptive use and risk of ovarian cancer. Obstet Gynecol 80: 708-714, 1992.

9. Risch HA, Marrett LD and Howe GR: Parity, contraception, infertility and the risk of epithelial ovarian cancer. Am J Epidemiol 140: 585-597, 1994.

10. Bosetti C, Negri E, Trichopoulos D, et al: Long-term effects of oral contraceptives on ovarian cancer risk. Int J Cancer 102: 262-265, 2002.

11. Wenham RM, Lancaster JM and Berchuck A: Molecular aspects of ovarian cancer. Best Pract Res Clin Obstet Gynaecol 16: 483-497, 2002.
12. Arends MJ, Morris RG and Wyllie AH: Apoptosis. The role of the endonuclease. Am J Pathol 136: 593-608, 1990.

13. Cohen JJ: Apoptosis. Immunol Today 14: 126-130, 1993.

14. Yu S, Lee M, Shin S and Park J: Apoptosis induced by progesterone in human ovarian cancer cell line SNU-840. J Cell Biochem 82: 445-451, 2001.

15. Bu SZ, Yin DL, Ren XH, Jiang LZ, Wu ZJ, Gao QR and Pei G: Progesterone induces apoptosis and up-regulation of p53 expression in human ovarian carcinoma cell lines. Cancer 79: 1944-1950, 1997.

16. Kalli KR, Bradley SV, Fuchshuber S and Conover CA: Estrogen receptor-positive human epithelial ovarian carcinoma cells respond to the antitumor drug suramin with increased proliferation: possible insight into ER and epidermal growth factor signaling interactions in ovarian cancer. Gynecol Oncol 94: 705-712, 2004.

17. Lindgren PR, Cajander S, Backstrom T, Gustafsson JA, Makela S and Olofsson JI: Estrogen and progesterone receptors in ovarian epithelial tumors. Mol Cell Endocrinol 221: 97-104, 2004.

18. Sartor O and Figg WD: Mifepristone: antineoplastic studies. Clinical Obstet Gynecol 39: 498-505, 1996.

19. Schneider MR, Michna H, Nishino Y and El Etreby MF: Antitumor activity and mechanism of action of different antiprogestins in experimental breast cancer models. J Steroid Biochem Mol Biol 37: 783-787, 1990.

20. Matsuda Y, Kawamoto K, Kiya K, Kuriso K, Sugiyama K and Uozumi K: Antitumor effects of antiprogesterones on human meningioma cells in vitro and in vivo. J Neurosurg 80: 527-534, 1994.

21. Lin MF, Kawachi MH, Stallcup MR, Grunberg SM and Lin FF: Growth inhibition of androgen-insensitive human prostate carcinoma cells by a 19-norsteroid derivative agent, mifepristone. Prostate 26: 194-204, 1995.

22. Rose FV and Barnea ER: Response of human ovarian carcinoma cell lines to antiprogestin mifepristone. Oncogene 12: 999-1003, 1996.

23. Murdoch WJ and van Kirk EA: Oestradiol inhibits spontaneous and cisplatin-induced apoptosis in epithelial ovarian cancer cells: relationship to DNA repair capacity. Apoptosis 2: 478-484, 1997.

24. Hamilton TC, Young RC, McKoy WM, et al: Characterization of a human ovarian carcinoma cell line (NIH:OVCAR-3) with androgen and estrogen receptors. Cancer Res 43: 5379-5389, 1983.

25. Andrews NC and Faller DV: A rapid micropreparation technique for extraction of DNA-binding proteins from limiting numbers of mammalian cells. Nucleic Acids Res 19: 2499, 1991 .

26. Treloar AE, Boynton RE, Behn BG and Brown BW: Variation of the human menstrual cycle through reproductive life. Int $\mathbf{J}$ Fertil 12: 77-126, 1967.

27. Feng YJ, Jin ZJ, Zhang XY, et al: A preliminary study of the inhibitory effects of medroxyprogesterone on human epithelial ovarian cancer. Chin J Obstet Gynecol 30: 93-95, 1995.

28. Syed V and Ho SM: Progesterone-induced apoptosis in immortalized normal and malignant human ovarian surface epithelial cells involves enhanced expression of FasL. Oncogene 22: 6883-6890, 2003.

29. Keith Bechtel M and Bonavida B: Inhibitory effects of 17betaestradiol and progesterone on ovarian carcinoma cell proliferation: a potential role for inducible nitric oxide synthase. Gynecol Oncol 82: 127-138, 2001.

30. McDonnel AC and Murdoch WJ: High-dose progesterone inhibition of urokinase secretion and invasive activity by SKOV-3 ovarian carcinoma cells: evidence for a receptor-independent non-genomic effect on the plasma membrane. J Steroid Biochem Mol Biol 78: 185-191, 2001.

31. Ho SM: Estrogen, progesterone and epithelial ovarian cancer. Reprod Biol Endocrinol 1: 73, 2003.

32. Kerr JF, Wyllie AH and Currie AR: Apoptosis: a basic biological phenomenon with wide-ranging implications in tissue kinetics. Br J Cancer 26: 239-257, 1972.

33. Schneider CC, Gibb RK, Taylor DD, Wan T and Gercel-Taylor C: Inhibition of endometrial cancer cell lines by mifepristone (RU 486). J Soc Gynecol Investig 5: 334-338, 1998.

34. Li DQ, Wang ZB, Bai J, Zhao J, Wang Y, Hu K and Du YH: Effects of mifepristone on proliferation of human gastric adenocarcinoma cell line SGC-7901 in vitro. World J Gastroenterol 10: 2628-2631, 2004.

35. Wang G, Shang HL, Xie Y, Xiao P, Li XJ, Lin TC and Li GY: Effects of mifepristone on the proliferation, apoptosis and cisdiamminedichloroplatinum sensitivity of cultured chemoresistant human ovarian cancer cells. Chin Med J (Engl) 118: 333-336, 2005 . 
36. Li Q, Li JJ, Zhao XB and Ji M: Study of effect of mifepristone on apoptosis of human ovarian cancer cell line $3 \mathrm{AO}$. Zhonghua Fu Chan Ke Za Zhi 38: 625-628, 2003.

37. Thomas M and Monet JD: Combined effects of RU486 and tamoxifen on the growth and cell cycle phases of the MCF-7 cell line. J Clin Endocrinol Metab 75: 865-870, 1992.

38. El Etreby MF, Liang Y and Lewis RW: Induction of apoptosis by mifepristone and tamoxifen in human $\mathrm{LNCaP}$ prostate cancer cells in culture. Prostate 43: 31-42, 2000.

39. Qin TN and Wang LL: Enhanced sensitivity of ovarian cell line to cisplatin induced by mifepristone and its mechanism. Di Yi Jun Yi Da Xue Xue Bao 22: 344-346, 2002.
40. Peters MG, Vanzulli S, Elizalde PV, Charreau EH and Goin MM: Effects of antiprogestins RU486 and ZK98299 on the expression of cell cycle proteins of a medroxyprogesterone acetate (MPA)induced murine mammary tumor. Oncol Rep 8: 445-449, 2001.

41. Pollett JB, Zhu YX, Gandhi S, et al: RU486-inducible retrovirus-mediated caspase-3 overexpression is cytotoxic to bcl-xL-expressing myeloma cells in vitro and in vivo. Mol Ther 8: 230-237, 2003

42. Liu Y, Wang LL and Deng Y: Enhancement of antitumor effect of cisplatin against human ovarian carcinoma cells by mifepristone in vivo. Di Yi Jun Yi Da Xue Xue Bao 23: 242-244, 2003.

43. Rocereto TF, Saul HM, Aikins JA Jr and Paulson J: Phase II study of mifepristone (RU486) in refractory ovarian cancer. Gynecol Oncol 77: 429-432, 2000. 